\title{
(WO)MAN IN THE MIRROR - A REFLECTION: LAW'S INFLUENCE ON SOCIETY, IDENTITY AND FEMINISM
}

\author{
by Devon-Lee Andriés*
}

\section{Introduction}

The law is a saviour to many in times of despair, a remedy for conflict and an instrument for change. However, despite its power and good work, many challenges arise in the application of the law. The law creates social structures and hierarchies that have a huge impact on society. The problem that I address in this essay is that these social structures influence and perhaps even hinder human identities. If society as a whole is impacted by factors such as stereotypes, gender roles and hierarchies, it makes sense that individuals would be easily swayed by a similar thing. These structures change the way humans see themselves and each other. Furthermore, women are affected to a larger extent by this problem in that patriarchy still reigns strong, despite society's best effort to transform in this regard. It seems that society 'programs' individuals into identifying themselves as the community does.

A legal system, which proposes one thing while implementing another, lacks integrity and accountability - values the Constitution aims for the South African legal system to uphold. I propose that a more open approach to the law will result in a legal system that provides for true freedom in dignity and identity for those falling under its jurisdiction. Furthermore, moving away from a modernist approach to a post structural, more general jurisprudence will lead to inclusion of women (providing a remedy to their oppression) and to a more substantially equal application of the law. I will be structuring my research around the work of a couple theorists and will use their perspectives to supplement my own argument. These include the work of Marx, ${ }^{1}$ Foucault, ${ }^{2}$ Veitch, ${ }^{3}$ Barnett, ${ }^{4}$ de Beauvoir, ${ }^{5}$

Final Year LLB Student, University of Pretoria.

As discussed in C Douzinas \& A Gearey Critical jurisprudence: The political philosophy of justice (2005).

As discussed in S Veitch Jurisprudence: themes and concepts (2nd ed) (2007).

Veitch (n 2 above).

$\mathrm{H}$ Barnett Introduction to feminist jurisprudence (1998).

$\mathrm{S}$ de Beauvoir The second sex (1949) Parshley, HM (ed and trans) (1988). 
Dowling, ${ }^{6}$ Botha $^{7}$ and Douzinas and Geary. ${ }^{8}$ To add flavour to this investigation, I will include some neuro-scientific perspectives based on the work of David Rock. ${ }^{9}$ Veitch ${ }^{10}$ suggests that the law plays a large role in protecting the autonomy of the individual - an area of great neuro-scientific research.

I will structure my findings around three research questions. In the first part I ask how it is that the law gives rise to social structures. Secondly, I look at how these social structures influence society's idea of gender roles. In this section I look deeper into the effect these structures have on women from a feminist perspective. Next, I ask what effect these societal structures have on an individual through a neuro-scientific lens. Finally, I will conclude by looking at a way forward and a solution to the abovementioned problem.

\section{How does the law create social structures?}

Section 9 of the Constitution states that all are equal before the law. ${ }^{11}$ This implies that our country is not hindered by the burden of rigid structures and hierarchies. It is made clear by Botha the paradox that exists in our law: The Constitution aims to free people from social categories of race and sex, and yet affirmative action, which should be remedying this, is feeding these very categories. ${ }^{12}$ Perhaps unpacking the work of Marx and Foucault will assist in understanding class structures and power dynamics in any society.

Marxism is a movement that fights against a capitalist society. Marxism aims to rid society of the structures that oppress the working class and give power to the bourgeoisie. Marx explains that every society is constituted in the following manner: the base of society is the economic system that governs it e.g. communism or capitalism. Birthed by this base while working to enforce it, is the superstructure that includes institutions, such as the law, which assist in enforcing the economic system. This super structure gives rise to a hierarchy by which the bourgeoisie are the rich class who own the means of production of such a society. The proletariats, who are the majority, the labour force, are also owned by the bourgeoisie. Lastly, the

6 DS Dowling 'The problem of gender stereotyping' (1998) 12 South African Journal on Higher Education 41.

7 H Botha 'Equality, plurality and structural power' (1995) 25 South African Journal on Human Rights 1.

8 Douzinas \& Gearey (n 1 above).

9 D Rock Your brain at work: strategies for overcoming distraction, regaining focus and working smarter all day long (2009); D Rock 'SCARF: a brain-based model for collaborating with and influencing others' (2008) 1 NeuroLeadership Journal 1; and D Rock \& $Y$ Tang 'Neuroscience of Engagement' (2009) 2 NeuroLeadership Journal 1.

10 Veitch (n 2 above) 264.

11 S 9 of the Constitution of the Republic of South Africa, 1996.

12 Botha (n 7 above) 1-2. 
lumper proletariats are the unemployed persons. The bourgeoisie exploits both the proletariats and lumper proletariats. The rich have power through money and use it to enhance their position in society. Marxism aims to emancipate the proletariats to free them of this oppression. ${ }^{13}$ Douzinas and Gearey criticise Marxism for being too modern an approach to the law. ${ }^{14}$ Marxism diminishes social being to nothing more than identification by the economy. ${ }^{15}$

Foucault is the father of power dynamics and is a poststructuralist. Foucault identifies two forms of power that govern society: sovereign power, which relates to those born with power, and normalising power, which relates to the right to control and administer life. As elements making up normalising power, Foucault distinguishes between discipline and biopower. ${ }^{16}$

Discipline is 'a mechanism of power which regulates the behaviour of individuals in the social body. ${ }^{17}$ This power is manifested through various forms of surveillance. Foucault uses the panopticon prison design by Jeremy Bentham as a metaphor for the monitoring of society by government. ${ }^{18}$ This design dictates that prisoners are constantly being watched by guards in a guard tower, which is central to the prison. ${ }^{19}$ These guards can see each and every cell. The idea here is that each individual acts as if they are constantly being watched, whether there is a guard in the tower or not. This is a way of regulating the behaviour of members of a community. Applying this to our society today, it is clear that perhaps we are being monitored through institutions such as schools, universities, South African Revenue Services (SARS) and the like. This can be seen as a form of imprisonment as individuals are not free to make their own decisions without a consequence or judgment. Perhaps there are some who are able to escape the walls of this monitoring, but many are confined and unable to break free from the mould in which society has placed them.

Biopower relates to the administration and production of life. ${ }^{20}$ This dictates that society has been governed to such an extent that we now govern ourselves. Foucault explains that power is not a thing, but rather a relation and it is present at even the most micro levels of social relations. ${ }^{21}$ Through understanding Foucault's ideas on power

13 https://www.marxists.org/reference/subject/philosophy/help/marxism.htm (Accessed 31 May).

14 Douzinas \& Gearey (n 1 above) 12.

15 As above.

16 Veitch (n 2 above) 265.

17 Michel-Focault.com 'Key Concepts' 30 October 2010 http://www.michelfoucault.com/concepts/index.html (accessed 31 May 2015).

18 Veitch ( 2 above) 267.

19 As above.

20 As above.

21 Michel-Focault.com 'Key Concepts' 30 October 2010 http://www.michelfoucault.com/concepts/index.html (accessed 31 May 2015). 
dynamics, it is clear that power gives rise to structures. Although Foucault disagrees with the structures created, he was able to identify them and suggest we move away from such a hierarchy. The law today, is a source of power and although power seems positive, perhaps it is the very thing hindering our freedom of identity.

Hobbes and Locke's ideas on the social contract into which all citizens enter, dictate that we give over our own power to the state in exchange for protection. As beneficial as this may seem for individuals, perhaps we are ultimately handing over our identities in conforming to that which society dictates we should be. Does the power of the state result in a decrease in our independence? It is possible that by allowing this difference in power, we are subjecting ourselves to ownership by the state just as the proletariats are owned by the bourgeoisie?

To summarise the above points, through the power dynamics and inherent levels of authority in any society, structures are created with or without the law. The law adds to these levels, a binding force which makes them a reality. It is clear that these structures will hinder the ability of society to find their own identities whilst they are under constant surveillance. This obligation to conform to society and abide by its rules, results in a suppression of the freedom we think we are afforded in a democratic society.

\section{How do these societal structures influence gender roles? A feminist perspective}

The first thing doctors assess at the birth of a child, and often even while the foetus is still developing, is the sex of the baby. As mentioned above, our Constitution provides for equality for all human beings, regardless of their sex. This begs the questions why the sex of a child is such a concern. Jurisprudence tutorial classes have influenced my thinking on the importance of the distinction between sex and gender. Sex relates to the biological make up of an individual - their reproductive organs, while gender refers to the sexual orientation of a person - the way in which they identify themselves. The gender of a person does not have to be and often isn't inline with their sex. Perhaps we could relate sex and gender to a restricted and general perspective on the law. Sex - a restricted determination of what a person shall be identified as, for the remained of their lives: a boy or a girl. Only two options - the answer is selected before a person has even breathed their first breath, let alone before they have the cognitive ability to make a choice (I will discuss the importance of choices to the human brain and functioning below). However, gender - the general approach, allows one to make this choice at any stage in their lives. This is an ever changing, more fluid 
concept. One may be a boy or a girl or anything in between. ${ }^{22} \mathrm{I}$ am aware of the flaw in this metaphor, as we will never be able to drive out sex or gender as a whole, as perhaps we could drive out a restricted or general approach to the law. However, we still have a choice as to whether sex or gender will be the factor by which we identify each other and ourselves.

Traditional societies often restrict a person to a heterosexual orientation. ${ }^{23}$ Should the law be structured to accommodate this traditional approach alone? Holmes so eloquently answers this question: 'It is ... revolting if the grounds upon which [a rule of law] was laid down have vanished long since, and the rule simply persists as a blind imitation of the past. 24 Douzinas and Gearey suggest that social being is not found through the 'static repetition of ... a series of laws' but through change and transformation in social relations. ${ }^{25}$

In Dowling's article, 'The problem of gender stereotyping, ${ }^{26}$ the focus is on the fact that although certain biological differences exist between men and women, the gender roles allocated to them by society are not justified sufficiently by those differences. ${ }^{27}$ Dowling presents a variety of arguments relating to gender roles. Regarding traditional domestic roles of men and women, women bear children and have the nurturing, caregiver abilities necessary for the maintaining of a household. ${ }^{28}$ Men, on the other hand, take on the role of providing food, clothing and financial maintenance of the mother and child. ${ }^{29}$ This seems to be the 'natural' arrangement of domestic roles, which leads to men and women assuming their positions as such. ${ }^{30}$ Wilson speaks of societies exaggerating the sexual differences of its members. ${ }^{31}$ This can be seen as a form of programming by society.

Men are most likely able to perform the duties of a woman, just as women are most likely able to perform a man's duties, but by exaggerating their sexual differences, which insinuate strength and rationality and weakness and emotion in men and women respectively, individuals are moulded to perform their traditional gender roles. Some may say that despite these allocated roles,

22 The LGBTQIA (lesbian, gay, bi-sexual, transgender, queer, intersexual or asexual) movement reiterates the various possibilities of gender - the spectrum of options from which an individual may choose to identify as.

23 R Jewkes \& R Morrell 'Gender and sexuality: Emerging perspectives from the heterosexual epidemic in South Africa and implications for HIV risk and prevention' (2010) 13 Journal of the International AIDS Society 9.

24 O Holmes 'The path of the law' (1897) 10 Harvard Law Review 469.

25 Douzinas \& Gearey (n 1 above) 11.

26 Dowling (n 6 above) 41.

7 As above.

28 As above.

29 As above.

30 As above.

31 EO Wilson On human nature (1978) 132. 
members of society are free to choose not to follow this same pattern. Wilson provides a counter argument to this: 'we are discouraged from trespassing on what is regarded as the other's role by various sorts of social disapproval. ${ }^{32}$ It is seen even in case law, that courts condone the set gender roles of society. In the Hugo case, the court had to decide whether or not to grant a presidential pardon to an imprisoned father. The court recognised that not granting the pardon would seem to be in favour of the stereotype that women are the primary caretakers of their children but still found that not granting the pardon was not unfair discrimination. ${ }^{33}$ Botha believes the court missed an opportunity to challenge these gender roles and allow for transformation of gender equality in South African legal precedent. ${ }^{34}$

In the past, women have been reduced to nothing more than glorified housekeepers. This is true to an extent in the work place. Women are undermined for being too emotional or for not being rational enough. Women experience a 'glass ceiling' which bars them from advancing to executive-level jobs. ${ }^{35}$ Ann Morrison describes this glass ceiling barrier as being so subtle that it is transparent, yet so strong that it prevents women from moving up the corporate hierarchy. ${ }^{36}$ Is there a way to avoid this oppression or are women born subject to it?

'One is not born but becomes a woman.' 37 The famous words of Simone de Beauvoir serve as food for thought when considering the influence society has on females. It is suggested that females are born females and then groomed by society to become women. Barnett looks at the reason women are still oppressed in society despite the formal equality provided through education, employment and the likes. ${ }^{38}$ Radical feminists argue that the law, which is a male dominant institution, supports the inequality of women. ${ }^{39}$ It is suggested that the inherent masculinity of the law prevents women being afforded the equality they appear to be given in the Constitution and legislation. To understand why this is, we should place the law in context to understand the history that brought it into existence. ${ }^{40}$ In the Persons case, Lord Sankey stated that:

The exclusion of women from all public offices is a relic of days more barbarous than ours, but it must be remembered that the necessity of

32 Wilson (n 31 above) as discussed in Dowling (n 6 above) 42.

33 President of the Republic of South Africa v Hugo 1997 (4) SA 1 (CC) as discussed in Botha ( $\mathrm{n} 7$ above) 18.

34 As above.

35 S Wärnich \& S Platt (eds) Human resource management in South Africa (2015) 114.

36 Feminist Majority Foundation 'Empowering women in business' 2014 http:// www.feminist.org/research/business/ewb_glass.html (accessed 1 June 2015).

37 de Beauvoir (n 5 above) 239.

38 Barnett (n 4 above) 21.

39 Barnett (n 4 above) 18

40 Barnett (n 4 above) 23. 
the times often forces on man customs, which in later years were not necessary. ${ }^{41}$

This quote brings to mind the importance of memory in our South African culture, as this is applicable to the courts' current approach to the law. Understanding where we come from and why certain laws were created will assist in understanding the purpose of such laws. That being said, if a law serves no purpose now, it should not exist. It is all very well to be able to recognise that a law existed out of necessity many years ago, but if we are a country of transformation, we should be constantly adjusting our laws to meet the needs of society. More women want to leave the home and build careers for themselves in the corporate world. Although formal equality dictates that this is allowed while in reality, there is a large amount of substantive equality lacking. Women are wanting to change the way they see themselves and the way they are identified by their peers. In order to do this, the law needs to be enforced in a gender-neutral manner. This will require in depth assessment of the laws governing women, women's rights and their application. To understand the purpose of laws in relation to women, let us look at what a woman really is and the needs of a large part of the population.

'Woman' is a socially constructed individual. ${ }^{42}$ To define the concept of a woman, it is essential to look at its opposite: men. ${ }^{43}$ When comparing these two concepts through the use of words such as 'masculine' and 'feminine', 'strength' and 'weakness' it is clear that men are seen as superior and women, inferior. ${ }^{44}$ Perhaps Derrida's thoughts on fundamental contradictions ${ }^{45}$ leading to a parasitic effect where one creature makes itself stronger by weakening another, could explain the way in which women are seen as inferior and "incidental"46 to men. Perhaps through enhancing the volume of women's voices, the oppression by societal structures and the law may be shifted to a more inclusive, general approach to women in society. By looking at women's experiences during times of oppression (i.e. memory), we are able to use the past as a basis from which to move forward in societal transformation. ${ }^{47}$ Barnett makes a very valid point in stating that the awareness of women needs to be increased because many women do not recognise oppression despite being the object of it. ${ }^{48}$ The inferiority of women has become so natural, that it is not disputed. ${ }^{49}$ De Beauvoir and other feminists argue that this

41 The Persons case ( $\mathrm{n}$ above) 128.

42 Barnett (n 4 above) 15.

43 As above.

44 As above - discussing the opinion of Jacques Derrida.

45 G Minda Postmodern legal movements: Jurisprudence at century's end (1995) 111.

46 de Beauvoir (n 5 above) 16

47 Barnett (n 4 above) 20.

48 Barnett ( $\mathrm{n} 4$ above) 12.

49 As above. 
acceptance stems from a 'socially fostered ignorance of women's alternatives'.$^{50}$ If women do not know any better, they do not realise the severity of their circumstances.

So, what the issue boils down to is this: over many centuries, society has been abiding with specific gender roles. These were created by the law at first and have continued to exist through human tradition. In terms of these gender roles, women are belittled and believed to be inadequate to compete with men - be that in the workplace, education or financial standing in society. Furthermore, many women do not realise they are being oppressed due to the normalness of their role as a caretaker or maintainer of the home. Furthermore, there is no obvious alternative to this role. This influences the way in which women see themselves and ultimately their identities. If women are not free to determine their role in their own home or workplace, it is not likely they will be able to form an individual identity. In our democratic society, our Constitution promotes freedom of all individuals, yet the traditional roles in society dictate women abiding by a pre-set routine and practice that provides no freedom or leeway. In addition to the effect these societal structures have on women, let us look at the impact they have on the human brain.

\section{How do societal structures influence the individual? A neuro-science perspective}

David Rock, co-founder of the Neuroleadership Institute, has focused his research in the field of social neuroscience, which looks at the way humans relate to each other and to themselves. ${ }^{51}$ The crux of Rock's work revolves around the SCARF model, an acronym for the five domains of human experiences: status, certainty, autonomy, relatedness and fairness. 52 These five domains activate either a 'primary reward' or 'primary threat' response in the brain. ${ }^{53}$ For example, if one feels the fairness of a situation has been threatened, their brain will react in the same way it would had their life been threatened. ${ }^{54}$ If a person's ego is boosted and therefore their status rewarded, their brain will respond as if they had received a monetary reward. ${ }^{55}$ Through a basic understanding of the brain, employers can enable increased employee productivity. It seems fitting to discuss autonomy and status in more depth, since these are most applicable to my research.

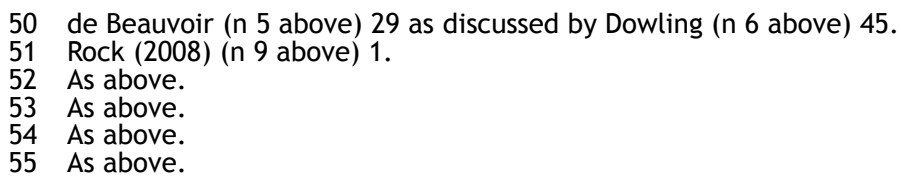


Autonomy can be defined as a person's ability to make his or her own choices and influence the outcome of a certain situation. This domain of the SCARF model, in application, dictates that if individuals have a choice between two or more options, or even the perception of choice, their reward circuitry will be activated. It is clear, therefore, that when individuals are micro-managed, and deprived of choice, the brain generates a strong threat response. ${ }^{56}$ This will send a person into the well-known fight or flight mode. This affects, among others, productivity and creativity. ${ }^{57}$ If we relate this example to society as a whole, it is possible that we are micro-managed by the government through various forms of regulation tactics. Furthermore, we are born into a world where our gender and roles in society have been decided before hand and we are groomed into a life of complying with that. This means we do not even get a choice regarding who or what we would like to identify as or with. Botha mentions that previously disadvantaged individuals are excluded from certain political communities and are therefore denied the right to exercise their own autonomy "to shape their identities". 58 Without choice about our own identities, the brain is in a constant mode of defence - fighting off what it perceives to be a life-threatening situation: a lack of autonomy. Perhaps the rebellion of many individuals in society can be attributed to the fact that social structures deprive them of making decisions regarding their own identities. For example, 'a study of teenagers in Western cultures found that teenagers have fewer choices than a felon in prison. ${ }^{59}$ These very communities experience teenage rebellion or the 'terrible teens' as it is commonly known, to a large extent. A coincidence? I think not.

Status, as an element of the SCARF model also seems applicable to a certain extent regarding human identification. Status has to do with importance relative to others, and seniority. ${ }^{60}$ This implies that when a person feels important and valued, this triggers their primary reward response. Perhaps in a society where many people are undermined and particularly women, as discussed above, feeling valued could make a significant difference to a person's engagement with society and productivity.

It is my belief that although social neuroscience has focused primarily on the workplace, if these factors are considered in the drafting of legislation, the deciding of judgments and the implementation of the law, this could make a huge impact. If members of the community feel important, and instrumental in 
making a decision and having a choice, and therefore rewarded, attitudes toward the law could change. This may lead to more obedience to the rules and regulations of society. Including these scientific factors in the implementation of the law could serve to expand our approach: a more general jurisprudence.

My argument regarding neuro-science is that if the brain is impacted through a lack of choice in the making of everyday decisions, we can only ask what the impact is when individuals are deprived of autonomy in decisions about their identity. If society's traditions and roles determine how individuals should be identified, this leaves them with no choice in the matter - a situation to which, we can see, the brain does not respond well. Furthermore, being categorised to match the standards of society's 'boxes' results in a lack of a feeling of importance and a decrease in the status of an individual. These outcomes give rise to the primary threat response described above. Prolonged stress results in high cortisol levels leading to ill health. This response should be avoided at all costs. In maximising performance in an organisation, it is proposed by Rock and Tang that the average level of activation of threat circuitry be reduced. ${ }^{61} \mathrm{It}$ is my view that leaders of our country and implementers of the law should aim to do the same. Deep engagement from a community is experienced when people feel rewarded from all five domains of SCARF. ${ }^{62}$

\section{Conclusion - the way forward: The law and our identity}

Through the above discussion, it is clear that social structures play a major role in the way humans identify themselves. Firstly, they are not able to make decisions regarding their identity without society 'programming' them to fit a mould that was determined many centuries ago. Through the gender roles allocated to individuals of different sexes, society is able to regulate the way in which people define their existence. Alongside being 'boxed' and categorised, women have the added pressure of trying to escape the inherent maleness of society. This engrained practice in society of undermining women is one that is difficult to suppress and changes the way women see themselves. This alters their identities without women even making a conscious decision to acknowledge such oppression. Furthermore, research has shown the impact on the brain of strict social structures, which restrict an individual's choice. Lack of

61 Rock \& Tang (n 9 above) 5.

62 Rock \& Tang (n 9 above) 3 - an example of a way to do this is through working for the greater good and improving some social condition. People in positions of power would benefit the community while benefiting themselves. 
autonomy regarding large life-altering decisions such as one's identity should not be hindered by outdated, irrelevant practices of society. It is my hope that a more general and open approach to the law will allow for a more inclusive approach to women. By considering factors other than just the economy, class, race and sex, hopefully we will be able to experience true transformation in our country. In bringing back the importance of individuality, identity and moral to the law, we may reignite the law's spirit. 'A law without a spirit is like a body without a soul: at best a corpse, at worst a zombie.'63

63 Douzinas \& Gearey (n 1 above) 18. 